\title{
Analysis of Influence Organizational Culture toward Intellectual Capital
}

\author{
Augustina Asih Rumanti, Trifenaus Prabu Hidayat, and Yordy
}

\begin{abstract}
Organizational culture commonly referred as work culture and is important in the SME (small and medium enterprises). If the organizational culture that is used in the SME is right and good then SME will go well. One of the assets owned by an SME is intellectual capital and it is an intangible asset that also plays an important role in an SME. This study wants to analyze the influence of organizational culture on the intellectual capital.

This study conducted by case study on Bina Karya SME that is located in Yogyakarta, Central Java, which is engaged in the wood handicrafts and souvenirs. In this study, the structural models developed from the results of the elaboration using the related theories are used. This structural model then produced a questionnaire that is used as a measuring tool in the study. Organizational culture has seven variables and intellectual capital has three variables in the research model. Data processing was performed by using software Smart PLS 2.

The results of this research show that organizational culture has an influence on the intellectual capital which means indirectly if the applied organizational culture is good and supportive in doing the work then it will increase the intellectual capital. From seven variables of organizational culture there are four variables influencing that is innovation and risk-taking, results orientation, team orientation, and aggressiveness while for all three variables of intellectual capital have effect that is human capital, structural capital and relational capital.
\end{abstract}

Index Terms-Organizational culture, intellectual capital, small and medium enterprises.

\section{INTRODUCTION}

An organization at a business in their activities would require human resources support for the achievement of the goals set by the organization. In achieving these goals many elements that are considered important in the fulfillment of which is applied in the organizational culture of a business. Cultural organizations also called the work culture. Organizational culture is difficult to define clearly and difficult to measure, but the culture of an organization can be perceived by the human resources within an enterprise. Along with the times, business competition is getting tighter, forcing the majority of SMEs to increase their assets. One of the sources and the wealth of a business is the intellectual capital or intellectual capital where it contains important elements that is the power of thought or knowledge. It can be seen that the organizational culture and intellectual capital is an

Manuscript received May 29, 2015; revised August 25, 2015. This work was supported in part by Atma Jaya Catholic University of Indonesia. Influence Analysis of Organizational Culture To Intellectual Capital (Case Study: UkmBinaKarya, Yogyakarta)

The authors are with the Atma Jaya Catholic in University of Indonesia, Indonesia (e-mail: augustina@atmajaya.ac.id, yordy_17@yahoo.com). important factor in a business as well as organizational culture and intellectual capital contained in each of the different businesses to see this suspect and researchers interested in knowing whether the organizational culture is also known as work culture have an influence on the intellectual capital which is an important asset in a business and want to know if there are significant also what are the factors that influence organizational culture and intellectual capital.

Formulation of the problem of this research is the analysis of the influence of organizational culture on the intellectual capital of a business. The purpose of this research is:

1) Identify the factors that influence organizational culture.

2) Identify the factors that influence the intellectual capital.

3) Identify the influence of organizational culture on the intellectual capital.

4) Analyze the influence of organizational culture on the intellectual capital.

\section{LITERATURE REVIEW}

\section{A. Organizational Culture}

Organizational culture is a system of meaning/significant jointly adopted by member that distinguishes the organization from other organizations. Based on this, it can be said that culture is a social and regulatory control running of the organization on the basis of values and beliefs that are shared, thus becoming the norm group work, and operationally called work culture as a guideline and behavior towards employees [1].

Dimensions are used to distinguish the culture of the organization there are seven primary characteristics that together capture the essence of the culture of the organization, namely: innovation and risk-taking, attention to detail, results orientation, the orientation of the individual, team orientation, aggressiveness, and stability [1].

\section{B. Intellectual Capital}

Some researchers revealed the definition of intellectual capital as follows [2]:

1) Intellectual Capital is elusive, but once discovered and exploited will provide a new source base organization to compete and win

2) Intellectual Capital is the term given to combining intangible assets from the market, intellectual property, infrastructure and human center can make a company function

3) The Intellectual Capital is intellectual material (knowledge, information, intellectual property, experience) that can be used to create wealth. It is a force to be collective or a set of useful knowledge 
4) Intellectual Capital is the effective use of knowledge work (finished product) as the position of the information (raw materials)

5) Intellectual Capital is considered as an element of the market value of the company and also the premium market.

6) Many practitioners who stated that intellectual capital consists of three main elements namely: Human Capital, Structural Capital, Relational Capital.

\section{Partial Least Square (PLS)}

Partial Least Square (PLS) is a powerful analytical method because it is not based on many assumptions. Data should not normal multivariate distribution (with a scale indicator category to the ratio can be used on the same model), the sample size should not be large and residual distribution [3].

Steps PLS-based structural equation modeling is as follows [3]:

1) Designing structural models (inner model)

2) Designing a measurement model (outer model)
3) Constructing the path diagram

4) Convert the path diagram in the system of equations

5) Parameter Estimation

6) Evaluation of goodness of fit

7) Testing Hypothesis (resampling bootstrapping)

\section{RESEARCH METHODOLOGY}

Organizational culture variables have some indicators obtained from literature in the form of the seven characteristics of organizational culture according to [4]. Seven characteristics it is innovation and risk-taking, attention to detail, results orientation, orientation to the individual, team orientation, aggressiveness, stability while there are three indicators of intellectual capital in the form of three main elements of intellectual capital is human capital, structural capital, and relational capital according to Stewart [2].

TABLE I: RESEARCH VARIABLES SPECIFICATIONS

\begin{tabular}{|c|c|c|c|}
\hline Reference & $\begin{array}{c}\text { Latent } \\
\text { variables } \\
\text { (Constructs) }\end{array}$ & $\begin{array}{l}\text { Manifest variables } \\
\text { (Indicators) }\end{array}$ & Operational Definitions \\
\hline \multirow{2}{*}{$\begin{array}{l}\text { Wulantika } \\
\text { (2011) }\end{array}$} & \multirow{2}{*}{$\begin{array}{l}\text { Organizational } \\
\text { Culture }\end{array}$} & Innovation and Risk Taking & $\begin{array}{l}\text { The extent to which the members of the organization are encouraged } \\
\text { to be innovative and take risks }\end{array}$ \\
\hline & & Attention to Detail & $\begin{array}{l}\text { The extent to which the members of the organization are expected to } \\
\text { exhibit precision, analysis and attention to detail. }\end{array}$ \\
\hline \multirow{5}{*}{$\begin{array}{l}\text { Wulantika } \\
\text { (2011) }\end{array}$} & \multirow{5}{*}{ Organizational } & $\begin{array}{l}\text { Results } \\
\text { Orientation }\end{array}$ & $\begin{array}{l}\text { The extent to which the management focus on results rather than the techniques and } \\
\text { processes used to achieve results. }\end{array}$ \\
\hline & & Orientation to the Individual & $\begin{array}{l}\text { The extent to which management decisions take into account the impact of the results on } \\
\text { the people in the organization, not only concerned with profits alone. }\end{array}$ \\
\hline & & Team Orientation & The extent to which work activities are organized to the team rather than an individual. \\
\hline & & aggressiveness & The extent to which the individual aggressive and competitive \\
\hline & & stability & $\begin{array}{l}\text { The degree to which the organization's activities emphasize the position of status rather } \\
\text { than organizational change }\end{array}$ \\
\hline \multirow{3}{*}{$\begin{array}{l}\text { Bontis } \\
(1999)\end{array}$} & \multirow{3}{*}{$\begin{array}{l}\text { Intellectual } \\
\text { Capital }\end{array}$} & Human Capital & $\begin{array}{l}\text { A very useful source of knowledge, skills, and competencies within an organization or } \\
\text { company. }\end{array}$ \\
\hline & & Structural Capital & $\begin{array}{l}\text { The ability of the organization or company to meet the company routines and structures } \\
\text { that support employee efforts to produce optimal intellectual performance and overall } \\
\text { business performance }\end{array}$ \\
\hline & & Relational Capital & $\begin{array}{l}\text { The ability to maintain a harmonious relationship/association network owned by the } \\
\text { company with its partners, both derived from the reliable and quality suppliers, comes } \\
\text { from loyal customers and satisfied will service the company concerned, derived from the } \\
\text { company's relationship with the government and with surrounding communities and } \\
\text { knowledge of the market share }\end{array}$ \\
\hline
\end{tabular}

\section{ANALYSIS}

\section{A. Measurement Validation Analysis}

Validation of the measuring instrument uses two parameters: the value of the loading factor and cross loading. An indicator as valid if it has a loading factor value above 0.5 but in this study the initial calculation, there are several indicators that have a factor loading values below 0.5 . The indicators that have a factor loading values below 0.5 are considered not appropriate to measure latent variables so that this indicator be discarded and re-calculation. After revising II it can be seen that all the indicators already have a factor loading values above 0.5 .

The research model can be seen in Fig. 2 .

Next validation measuring instrument can be seen from the cross loading where the value of cross loading an indicator should be higher than the value of cross loading other indicators in order to be valid. Differences of cross loading the loading factor is the value of cross loading shows a comparison of an indicator to measure the construct than used to measure other constructs. From the data processing is known, there are several indicators that have a value in a variable cross loading its manifestation is smaller when compared with the value of the other manifest variables indicators that have value in the variable cross loading its 
manifestation is smaller when compared with the value of the other manifest variables omitted as not precisely measure its manifestation variables and re-calculation. After revising IV are known for loading factor values of all the variables already have values above 0.5 and for the value of cross loading all the indicators already has the highest value in its manifestation variables compared with other manifest variables that indicate that the indicator is appropriate to measure its manifestation variables.
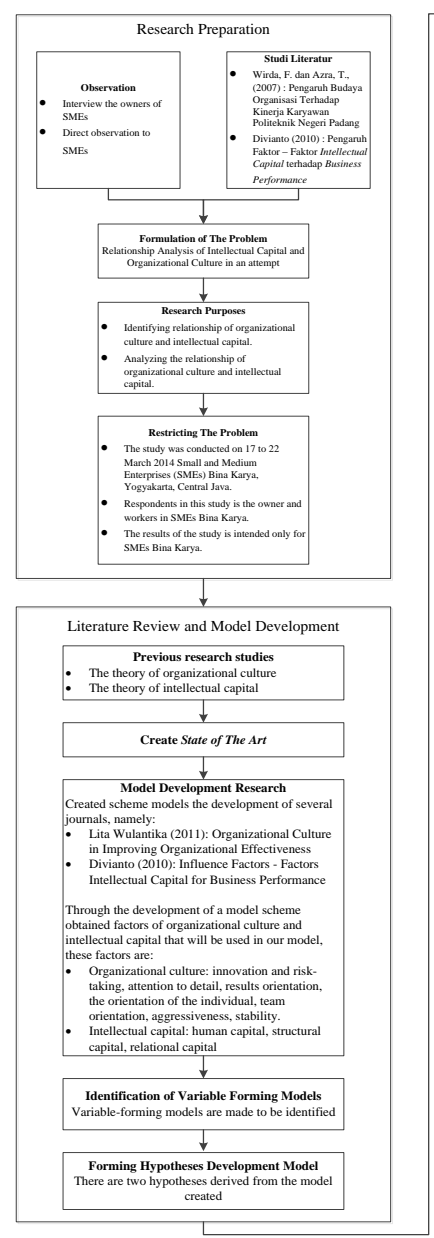

Fig. 1. Research methodology.

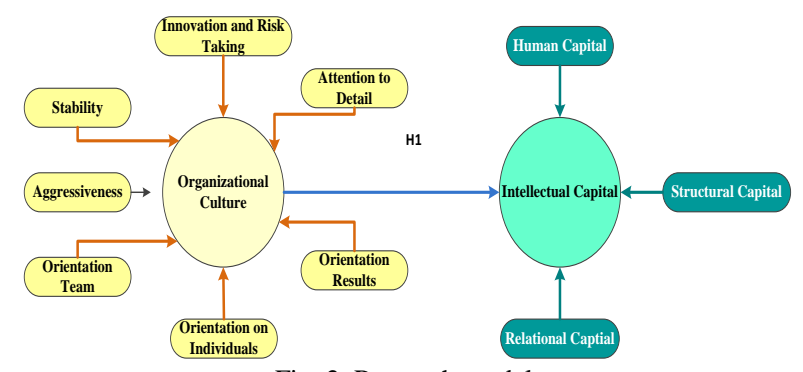

Fig. 2. Research model.

There are many indicators used to measure variables invalid manifest this can be caused by items of statements made to an indicator variable cannot explain its manifestation and can also be caused by people who responded to the questionnaire do not understand the purpose of the statements contained in the indicator so that one of the interpret the statement.

\section{B. Reliability Analysis of Research Variables}

The reliability of this study seen from the AVE (Average
Variance Extracted) and CR (Composite Reliability) of output data processed using software Smart PLS 2. A said to be reliable if the variable has a value above $0.5 \mathrm{AVE}$ and $\mathrm{CR}$ values above 0.7 . In this study the value AVE and CR seen after revising IV and known value of AVE and CR values for all the variables already have values above 0.5 (for the AVE) and above 0.7 (for CR) so that it can be said of all the variables used in this study has been reliable and has good reliability.

\section{Significant of Variables in Model Research}

The level of Significant can be identified from the value of the T-statistic. Significant can be met if the value of the T-statistic greater than 2,776 variables. 2776 values obtained from table $\mathrm{T}$ distribution with the use of an alpha of 0.05 and the number of respondents is 5 people, so that the table $\mathrm{T}$ distribution must be alpha 0:05 with $v=n-1=5-1=4$. Here is the value of the T-statistic results of data processing.

From Table II it can be seen that the factors that have a significant impact on organizational culture is innovation and risk taking, results orientation, team orientation, and aggressiveness. Factors that have a significant influence on the intellectual capital is human capital, structural capital and relational capital.

In the latent variable of organizational culture manifest there are three variables that do not have significant influence is attention to detail, individual orientation, and stability. Seeing this Bina Karya SMEs should consider factors of innovation and risk-taking, results orientation, team orientation, and aggressiveness to apply organizational culture and factors of human capital, structural capital and relational capital to increase the intellectual capital to SMEs.

\section{Variability Analysis of Research Model}

Variability research model can be seen from the R-square value. R-Square value can be seen in Table 3 below.

$\mathrm{R}$-square values of the culture of the organization is at 0.334319 which means the variance that can be explained by its manifestation variable is equal to $33.4319 \%$ and $66.5681 \%$ is explained by other factors and to the R-square for organizational culture is moderate while the R-square value of intellectual capital 1 which shall mean variance that can be explained by its manifestation variable is equal to $100 \%$ and $\mathrm{R}$-square for intellectual capital is strong.

\section{E. Research Hypothesis Analysis}

Culture within the company is a key step for the development of intellectual capital [5] and also [2] said that intellectual capital is elusive, but once found and exploited it is likely to provide an organization with a new resource [6]. Based on both the statement alleged that organizational culture has an influence on the intellectual capital and also compiled this hypothesis. Hypothesis of the study are follows: $\mathrm{H}_{0}=$ Organizational Culture does not affect intellectual capital

$\mathrm{H}_{1}=$ Organizational Culture affects intellectual capital

Hypothesis testing is done by looking at the value of the T-statistic on the path coefficient. Value T-subset of the statistics accepted if greater than $\mathrm{T}$ table that is equal to 2,776 . $\mathrm{T}$-statistic values greater than 2,776 will be made welcome and vice versa $\mathrm{H} 1 \mathrm{~T}$-statistic values smaller than 2776 will 
make $\mathrm{H} 1$ is rejected.

T-statistic value obtained is equal to 3.777964 so statistically the value of the T-statistic $>\mathrm{T}$ table which causes the value of the T-statistic is in the critical region and the decision is received $\mathrm{H} 1$ and it can be said that the organizational culture affects intellectual capital.

TABLE II: VARIABLE SIGNIFICANT RESEARCH MODEL

\begin{tabular}{|c|c|c|c|c|}
\hline Latent Variable & Manifest Variable & $\begin{array}{l}\text { Composite } \\
\text { Reliability }\end{array}$ & T-Stat & Sig \\
\hline \multirow{7}{*}{ Organizational Culture (A) } & $\begin{array}{l}\text { Innovation and Risk Taking } \\
\text { (A1) }\end{array}$ & 0.95 & 13.46 & $\sqrt{ }$ \\
\hline & $\begin{array}{l}\text { Attention to Detail } \\
\text { (A2) }\end{array}$ & 0.55 & 1.45 & $\mathrm{X}$ \\
\hline & Results orientation (A3) & 0.97 & 6.77 & $\sqrt{ }$ \\
\hline & The orientation of the individual (A4) & 0.75 & 1.72 & $\mathrm{X}$ \\
\hline & Orientation Team (A5) & 1 & 4.03 & $\sqrt{ }$ \\
\hline & Aggressiveness (A6) & 1 & 6.88 & $\sqrt{ }$ \\
\hline & Stability (A7) & 0.69 & 1.73 & $\mathrm{X}$ \\
\hline \multirow{3}{*}{ Intellectual Capital (B) } & Human Capital (B1) & 1 & 12.14 & $\sqrt{ }$ \\
\hline & Structural Capital (B2) & 0.94 & 24.14 & $\sqrt{ }$ \\
\hline & Relational Capital (B3) & 0.93 & 8.48 & $\sqrt{ }$ \\
\hline
\end{tabular}

\section{F. Influence Analysis of Organizational Culture to Intellectual Capital}

TABLE III: R-SQUARE VALUE

\begin{tabular}{|c|c|}
\hline Dependent Variable & R Square \\
\hline Organizational culture & 0.334319 \\
\hline Intellectual Capital & 1 \\
\hline
\end{tabular}

In the research model used in this study there are two latent variables, namely organizational culture and intellectual capital, for the latent variable of organizational culture has seven manifest variables, namely innovation and risk-taking, attention to detail, results orientation, orientation to the individual, team orientation, aggressiveness, and stability. From seven manifest variables are known, there are four significant variables innovation and risk-taking, results orientation, team orientation, aggressiveness and three variables are declared not significant attention to detail, the orientation of the individual, and stability. This means that for innovation and risk-taking, results orientation, team orientation, and aggressiveness have an influence on organizational culture [7]. Innovation and risk-taking has an influence on organizational culture in which it is seen in giving employees the freedom to determine the method of doing his job, act and account for his actions [8]. For orientation results have an influence in terms of more importance than the process of his work and also known in the SME Development work in making handicrafts everyone in SMEs have their own way and so will be more concerned with different work outcomes than process. Orientation team has influence in the culture of the organization in terms of completing the task in which the tasks are better addressed in the work team and to aggressiveness have influence in ways that are used every individual to get his wish. In conducting the process is also SMEs Bina Karya accomplish more by working team and always trying to get his wish.

Latent variable intellectual capital has three manifest variables and three variables that influence its manifestation have human capital, structural capital and relational capital. Human capital here is closely related to the source of knowledge, skills and competencies that if those three things, the better the intellectual capital that is an intangible asset will be better. Structural capital which is closely related to the organization's ability to meet the routine process to provide welfare to employees and support the development of new ideas and relational capital here is the ability to maintain relationships with customers or partners and continue to increase market share where to structural capital and relational capital will certainly affect the intangible assets of SMEs Bina Karya where if the ability of the organization and in maintaining relationships with its partners, the better then of intangible assets in the SME Development work is increasing. Of data processing can also be said that organizational culture has an influence on the intellectual capital and it can be said that a good organizational culture and support in doing the work would increase the intellectual capital in an SME in the case study was conducted in SMEs Bina Karya.

\section{DISCUSSION AND CONCLUSION}

Based on the stages that have been done before in this study, especially in data processing and analysts, we can conclude a few things like the following:

1) Factors that influence organizational culture is innovation and risk taking, results orientation, team orientation, and aggressiveness.

2) Factors that influence the intellectual capital is human capital, structural capital and relational capital.

3) Organizational culture has an influence on the intellectual capital in SMEs Bina Karya.

4) In a study conducted in SMEs Bina Karya proved that organizational culture has an influence on the intellectual capital that can be said in SME Development work if the organizational culture or commonly referred to as a work culture that is applied right and good to pay attention to the factors that influence the organizational culture in SMEs Bina Karya (is is innovation and risk-taking, results orientation, team orientation, and aggressiveness) then it will create intellectual capital which is an intangible asset in SMEs increased and better. 


\section{SUGGESTION}

Advices that can be given to SMEs Bina Karya to consider are as follows:

1) Development of SMEs should be able to apply the work culture of the organization or referred to as culturally appropriate and good work by taking into account factors such as are innovation and risk-taking, results orientation, team orientation, and aggressiveness. Organizational culture that is applied in SMEs Bina Karya should give freedom to employees in performing their work methods and accountable actions, concerned with the results of the work are made, the work accomplished by the working team, and always support the employee to fulfill his wish. Organizational culture that is applied with regard to these factors will make the intellectual capital in the SME Development work is increased and become better.

2) SME Development work should also pay more attention to factors such as human capital, structural capital and relational capital with continued attention and train him to be the best in the field, supporting the development of new ideas, continue to maintain a good relationship with the consumer, and continues to increase its market share. If these three factors increased or directed to be better, it will create intellectual capital which is an intangible asset in growing SMEs Bina Karya.

\section{ACKNOWLEDGMENT}

Authors thank Atma Jaya Catholic University of Indonesia for providing the supporting facility in conducting the research. Authors would also like to thank the owner of SMEs Bina Karya for the opportunity given in conducting in research by providing supportive data so the research could be seamlessly conducted.

\section{REFERENCES}

[1] L. Wulantika, Budaya Organisasi Dalam Meningkatkan Keefektifan Organisasi, Majalah Ilmiah Unikom, vol. 7, no. 2, pp. 207-216, 2011.
[2] N. Bontis, "Managing organizational knowledge by diagnosing intellectual capital: Framing and advancing the state of the field," International Journal Technology Management, vol. 18, no. 5, pp 433-455, 1999.

[3] I. Ghozali, Structural Equation Modeling Metode Alternatif dengan Partial Least Square, Semarang: Universitas Diponegoro, 2006.

[4] G. Probst, S. Raub, and K. Romhardt, Managing Knowledge Building Blocks for Success, John Wiley \& Sons Ltd, Chichester, England, 2000.

[5] I. Nonaka and H. Takeuchi, The Knowledge - Creating Company, New York, U.S.: Oxford University Press, 1995.

[6] V. Ambrosini and J. Billsberry, Person-Organisation Fit: An Invisible Hand Facilitating the Transfer of Tacit Knowledge, pp. 1-8, 2007.

[7] Divianto, Jurnal Ilmiah Orasi Bisnis Edisi ke-IV, pp. 81-99, 2010.

[8] S. M. S. Canizares, M. A. A. Munoz et al., "Organizational culture and intellectual capital: A new model," Journal of Intellectual Capital, vol. 8, no. 3, pp. 409-430, 2007.

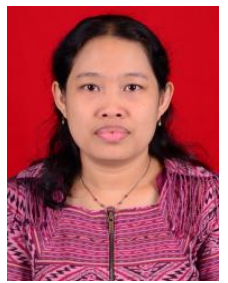

Augustina Asih Rumanti was born in Surabaya, on August 11, 1980. She is a lecturer at the Department of Industrial Engineering, Atma Jaya Catholic University in Indonesia, Jakarta. She received a master degree from Bandung Institute of Technology Indonesia in 2009. Her current interest research are in the area of organization development, knowledge management and management of technology.

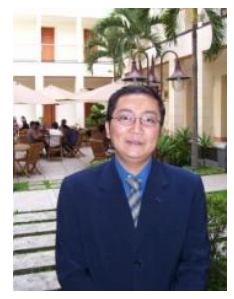

Trifenaus Prabu Hidayat was born in Surakarta, on May 19, 1980. He is a lecturer at the Department of Industrial Engineering, Atma Jaya Catholic University in Indonesia, Jakarta. He received a master degree from Bandung Institute of Technology Indonesia in 2007. His current interest research are in the area of modeling and simulation system.

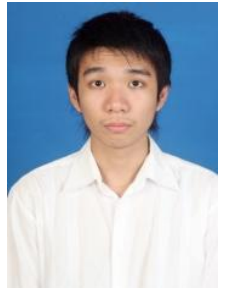

Yordy was born in Jakarta, on October 17, 1993. He majored in industrial engineering at Atma Jaya Catholic University in Indonesia, Jakarta, Indonesia in 2015 and graduated with honors. 